\title{
Prevalence of xerostomia in women during breast cancer chemotherapy
}

\author{
Prevalência da xerostomia em mulheres durante a quimioterapia por câncer de mama \\ Prevalencia de la xerostomía en mujeres durante la quimioterapia por cáncer de mama
}

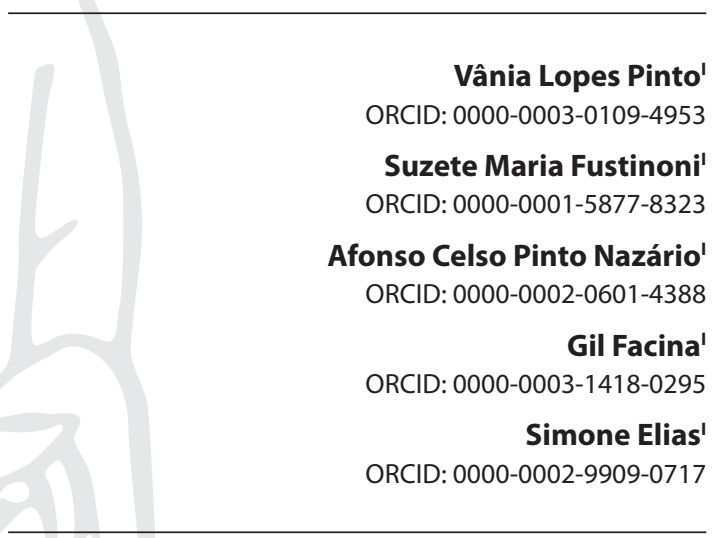

'Universidade Federal de São Paulo. São Paulo, São Paulo, Brazil.

How to cite this article:

Pinto VL, Fustinoni SM, Nazário ACP, Facina G,

Elias S. Prevalence of xerostomia in women during breast cancer chemotherapy.

Rev Bras Enferm. 2020;73(Suppl 4):e20190785. doi: http://dx.doi.org/10.1590/0034-7167-2019-0785

\section{Corresponding author:}

Vânia Lopes Pinto

E-mail: vania.lopes@unifesp.br

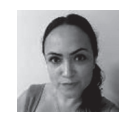

EDITOR IN CHIEF: Antonio José de Almeida Filho ASSOCIATE EDITOR: Ana Fátima Fernandes

Submission: 01-23-2020 Approval: 05-21-2020

\begin{abstract}
Objective: To identify the prevalence of xerostomia in women undergoing chemotherapy for breast cancer. Method: Prospective cohort with 27 women who underwent up to 16 sessions of intravenous chemotherapy. Data collection was performed at the outpatient clinic of a university hospital in the city of São Paulo, where two forms were applied before the start of treatment and the Xerostomia Inventory before and after each chemotherapy session. Results: Complaints of dry mouth were present in $48.1 \%$ of women before chemotherapy, and they were approximately 28 times more likely to develop dry mouth during treatment. It was observed that the use of antiemetics contributed to the occurrence of xerostomia, and the anti-ulcerous were presented as a protective factor. Conclusion: The study identified both a high prevalence of xerostomia regardless of the chemotherapy used and the need to create protocols to improve the quality of life of these patients.

Descriptors: Xerostomia; Breast Neoplasms; Drug Therapy; Women; Antineoplastic Agents.
\end{abstract}

\section{RESUMO}

Objetivo: Identificar a prevalência da xerostomia nas mulheres em tratamento quimioterápico por câncer de mama. Método: Coorte prospectiva com 27 mulheres que realizaram até 16 sessões de quimioterapia endovenosa. A coleta de dados foi realizada no ambulatório de um hospital universitário na cidade de São Paulo, onde foram aplicados dois formulários antes do início do tratamento e o Xerostomia Inventory antes e após cada sessão de quimioterapia. Resultados: A queixa de boca seca esteve presente em $48,1 \%$ das mulheres antes da quimioterapia, e elas tiveram aproximadamente 28 vezes mais chance de desenvolver a xerostomia durante o tratamento. Observou-se que o uso de antieméticos contribuiu para a ocorrência de xerostomia, e os antiulcerosos se apresentaram como fator de proteção. Conclusão: $O$ estudo identificou tanto uma alta prevalência de xerostomia independentemente da quimioterapia empregada quanto a necessidade da criação de protocolos visando à melhoria da qualidade de vida dessas pacientes.

Descritores: Xerostomia; Neoplasias da Mama; Tratamento Farmacológico; Mulheres; Antineoplásicos.

\section{RESUMEN}

Objetivo: Identificar la prevalencia de la xerostomía en las mujeres en tratamiento quimioterápico por cáncer de mama. Método: Cohorte prospectiva con 27 mujeres que realizaron hasta 16 sesiones de quimioterapia endovenosa. La recogida de datos ha sido realizada en el ambulatorio de un hospital universitario en la ciudad São Paulo, donde han sido aplicados dos formularios antes del inicio del tratamiento y el Xerostomia Inventory antes y después de cada sesión de quimioterapia. Resultados: La queja de boca seca estuvo presente en $48,1 \%$ de las mujeres antes de la quimioterapia, y ellas tuvieron aproximadamente 28 veces más chance de desarrollar la xerostomía durante el tratamiento. Se observó que el uso de antieméticos contribuyó para la ocurrencia de xerostomía, y los antiulcerosos se presentaron como factor de protección. Conclusión: El estudio identificó tanto una alta prevalencia de xerostomía independientemente de la quimioterapia empleada cuanto la necesidad de la creación de protocolos visando a la mejoría de la calidad de vida de esas pacientes. Descriptores: Xerostomía; Neoplasias de la Mama; Quimioterapia; Mujeres; Antineoplásicos. 


\section{INTRODUCTION}

Breast cancer is the most common cancer among women in the world. In 2020, the world estimate is 2,179,457 new cases, with an increase of 880,372 cases in the projection made by the International Agency for Research on Cancer for the year 2040(1).

The disease ranks first in all Brazilian regions ${ }^{(2)}$, and the triennium estimate (2020-2022) published by the National Cancer Institute (INCA) is 66,280 new cases, with an increase of 6,580 cases compared to the 2018-2019 estimate ${ }^{(2-3)}$.

Among the main treatments used to fight breast cancer are conservative or radical surgery, chemotherapy, endocrinotherapy, target therapy and radiotherapy ${ }^{(4)}$. All can cause side effects, but chemotherapy is what most acutely affects quality of life. Commonly associated symptoms are pain, inflammation, fatigue, nausea and vomiting, diarrhea, febrile neutropenia, skin changes, mucositis and dry mouth ${ }^{(4)}$.

Xerostomia is defined by some authors as a subjective sensation of dry mouth, usually associated with decreased salivary flow, which may arise during chemotherapy, when radiotherapy is applied in or near the oral cavity ${ }^{(5-6)}$.

Chemotherapy acts on the destruction or inhibition of cell growth, not differentiating neoplastic cells from normal ones, which can lead to myelosuppression. This fact, when observed in the oral cavity, on average from the 7th to the 10th day after the administration of chemotherapy, presents a predisposition to the appearance of dry mouth and oral infections such as candidiasis, in addition to halitosis, the appearance of lesions, burning mouth, difficulties in chewing, swallowing and speech, as well as decreased taste. All of this has consequences for general health, such as poor nutrition, problems in social relationships and sleep, compromising quality of life ${ }^{(5,7-9)}$.

Studies describing the prevalence of xerostomia in the general population are rare. One carried out in Sweden, in 2009, with both sexes and age from 50 years old, presented an estimated rate of $13 \%{ }^{(10)}$. In 2019, these same authors investigated the same problem in the population aged 50 to 80 years and concluded that there is a high prevalence of xerostomia among the elderly, especially in women, which needs to be taken into account when assessing their oral health and in providing dental care by age group ${ }^{(11)}$.

In Brazil, the most current xerostomia prevalence is described in the city of Piracicaba, with a rate of $17 \%^{(12)}$; and in the systematic review of 2018, in which the percentage was 22\%, with high heterogeneity between studies ${ }^{(5)}$.

In cancer patients undergoing chemotherapy, the prevalence of this complaint was analyzed in a descriptive study conducted in the southern region of the state of Ceará, in 2015, with men (39.7\%) and women (60.3\%). Xerostomia has been shown to be the most common oral pathological condition among these patients, with an estimated frequency of $77.3 \%{ }^{(13)}$.

Among the studies that address breast cancer, chemotherapy and the presence of xerostomia, we highlight one carried out in India, in 2017, with 52 women, in which xerostomia was evaluated before $(0 \%)$, during chemotherapy (65.4\%) and after treatment $(44.2 \%)^{(14)}$.

Given the above, we seek to answer the guiding question: "What is the prevalence of xerostomia in women with breast cancer undergoing chemotherapy?". There are few publications on this prevalence, the theme is little explored in the field of nursing, and most studies focus on the area of dentistry, being a problem of clinical relevance for all patients undergoing chemotherapy.

We hope that the study will contribute to the performance of the nursing team directly involved in the care of these patients, creating protocols to reduce xerostomia and quality of life for this population.

\section{OBJECTIVE}

Identify the prevalence of dry mouth in women diagnosed with breast cancer and undergoing chemotherapy.

\section{METHODS}

\section{Ethical aspects}

The study was developed in accordance with Resolution No. 466 of 2012 of the National Research Ethics Commission (CONEP) and with the rules of the Research Ethics Committee of the Federal University of São Paulo / UNIFESP, which regulate research involving human beings; and the research project was approved by the ethics committee.

The participants signed the Free and Informed Consent Term (FICT) in two copies: one for themselves and the other for the researcher.

\section{Study design, period and location}

This is a prospective longitudinal cohort study carried out between October 2016 and January 2018 at the Mastology Clinic of the Department of Gynecology of the Hospital São Paulo / University Hospital of the Federal University of São Paulo - UNIFESP.

\section{Study population; inclusion and exclusion criteria}

For the calculation of the sample size, the formula for finite populations and qualitative variable was used, considering the 95\% confidence level, the unknown prevalence of the event in the studied population of $50 \%$, the average number of women who are submitted to chemotherapy treatment for breast cancer in the service where the research was carried out (143 women / year) and an initial sample error of $15 \%$, which was corrected for $17 \%$.

58 women with a diagnosis of breast cancer and indication for neoadjuvant or outpatient adjuvant chemotherapy were invited to participate in the study. Of these, 33 accepted the invitation. The exclusion criteria were: the change from chemotherapy treatment to another such as radiotherapy or endocrinotherapy (one participant), abandonment of treatment (one participant), interruption of chemotherapy due to clinical conditions that required hospitalization (one participant) and the withdrawal from participating in the (three participants), with 27 women remaining until the end of the study.

\section{Study protocol}

Two forms constructed by the researchers were used, applied only before chemotherapy: one for recording sociodemographic data and the other for anamnesis related to the oral cavity. 
The oral assessment was self-reported by the participants when asked about the presence of oral sores, changes in taste, problems with swallowing, bleeding gums, dry mouth, bad breath, problems with chewing, sensitivity, pain in teeth, teething failures, discomfort prosthesis and others. The answers were dichotomous (yes or no) and in relation to the last week.

We also used the Xerostomia Inventory, original version, created by Thomson in 1999, in the USA, validated and cross-culturally adapted in Portuguese to assess xerostomia. This inventory consists of 11 items designed to assess various situations of dry mouth sensation (feels dry mouth; dry lips; wakes up at night to drink water; feels dry mouth during meals; consumes a little liquid to help swallow food; sucks candy or chewing gum to relieve cough and / or dry mouth; feels dry face; dry eyes; has difficulty swallowing certain foods; feels the inside of the nose dry; have difficulty eating dry foods), with five response options, with scores ranging from 1 to 5 . The sum result can vary from 11 to 55 points, and the closer to 55, the greater the degree of xerostomia ${ }^{(15-16)}$.

We call "zero time" the moment before chemotherapy in which the two forms and the Xerostomia Inventory were applied. This was done by the same researcher during the entire data collection period, in person, referring to the last week.

Through face-to-face action, the participant would already be familiar with what would be asked by phone between the 7th and 10th day after each chemotherapy session. This moment of the research, we call "follow-up". We opted for the application via telephone to avoid the displacement of the participant and, thus, minimize losses during this phase of the research.

The Xerostomia Inventory was applied at follow-up at least 4 times and at most 16 times per participant during treatment, as the chemotherapy sessions varied according to the chemotherapy scheme defined for each one.

\section{Data analysis and statistics}

The data was compiled and analyzed using the SPSS statistical program, version 23.

For the descriptive analysis of continuous variables, mean, standard deviation, median, minimum and maximum were calculated; and, for categorical variables, frequency and percentage were calculated.

Fisher's exact test or likelihood ratio test was used to compare xerostomia before chemotherapy with the variables of interest. To compare them with xerostomia taking into account the sessions performed, the generalized estimation equation model (GEE) and the logistic regression model were used, with a significance level of $5 \%(p<0.05)$.

\section{RESULTS}

All women in the study were from the state of São Paulo and users of the Unified Health Service (SUS), aged between 35 and 77 years, with an average of 53 years, standard deviation of 9 years and median of 53 years. Still, $14.8 \%$ were smokers; $22.2 \%$, alcoholics; $25.9 \%$ were overweight; and $22.2 \%$ in grade 1 obesity.

Among pre-existing diseases, systemic arterial hypertension was present in $48.1 \%$ of women, followed by hypercholesterolemia (18.5\%), depression (14.8\%) and diabetes (11.1\%). Gastritis was reported by $7.4 \%$, and other diseases had a percentage of
$3.7 \%$, such as hyperuricemia, asthma, anxiety, dermatomyositis, schizophrenia, stomatitis, gastric hernia and varicose ulcer.

Among the medications used before chemotherapy, anti-dislipidemics are used, used by $48.1 \%$ of women, analgesics $(25.9 \%)$, anti-hypertensives (22.2\%), anti-inflammatory drugs (18.5\%), antidepressants (14.8\%), anti-ulcer (14.8\%) and oral antidiabetics (11.1\%).

When asked, through the anamnesis form referring to the oral cavity, about complaints in the mouth region in the last week before the start of chemotherapy, $48.1 \%$ reported dry mouth; bad breath, problems with chewing, tenderness or pain in the teeth, flaws or soft teeth were reported in $18.5 \%$ of women; oral wounds, in 14.8\%; and bleeding gums, in $11.1 \%$. Prosthesis discomfort, altered taste and swallowing problems occurred in 7.4\%; and general discomfort, in 3.7\%.

By associating the complaints referred in the anamnesis of the oral cavity with the presence of xerostomia in the follow-up by the Xerostomia Inventory, women who reported dry mouth before chemotherapy had approximately 28 times more (adjusted) chance of developing xerostomia than those who did not this complaint, according to Table 1.

There was no significance in the association of xerostomia with the variables age, family income, education, habits (tobacco, alcohol), diseases, use of previous medications, body mass index (BMI) (17) and oral complaints (except dry mouth) before chemotherapy.

Table 2 shows the chemotherapy regimens performed in the study population, with the one with doxorubicin hydrochloride and cyclophosphamide (AC) followed by paclitaxel ( $T$ ) being the most used.

After evaluating all 394 inventories (total number of Xerostomia Inventory applied before and following the 27 participants), the prevalence of xerostomia was observed at $75.4 \%$, with an average score of 18.8 points on the Xerostomia score Inventory.

Of the 21 participants who underwent 16 chemotherapy sessions, two who used paclitaxel (taxol) reported xerostomia in only four sessions. The four with doxorubicin hydrochloride and cyclophosphamide (AC) followed by taxol and trastuzumab (TH) reported xerostomia in all sessions, with a frequency of $100 \%$ in three sessions with the drug $\mathrm{AC}$ and one session with the drug $\mathrm{TH}$.

Xerostomia was also present in all sessions of the 15 women who received $A C+T$, in which $93.3 \%$ presented it in the $3 \mathrm{rd}(A C)$ and 14 th session $(T)$.

All four women with docetaxel and cyclophosphamide (CT) regimen reported xerostomia in the first three sessions, and the woman who received cyclophosphamide, methotrexate and fluorouracil (CMF) presented it only in the first session.

The use of anti-hypertensives, analgesics, oral antidiabetics and corticosteroids did not contribute to the onset of xerostomia before or during chemotherapy.

All women who used antidepressants reported xerostomia before and during follow-up, however, as well as those using anti-inflammatory and anti-lipid drugs, there was no significance in the association with the complaint.

The prevalence of xerostomia before and during chemotherapy in users of anti-ulcer agents was lower than in those who did not use this medication, a fact observed after the last session in which women who did not use it presented a 22-fold chance for the occurrence of xerostomia, as observed in Table 3. 
Table 1 - Xerostomia for variables of interest (before chemotherapy), São Paulo, Brazil, 2019

\begin{tabular}{|c|c|c|c|c|c|c|c|}
\hline & \multirow[b]{2}{*}{$\mathbf{n}$} & \multicolumn{3}{|c|}{ Gross } & \multicolumn{3}{|c|}{ Adjusted } \\
\hline & & $p$ value & OR & $95 \% \mathrm{Cl}$ & $p$ value & OR & $95 \% \mathrm{Cl}$ \\
\hline \multicolumn{8}{|l|}{ BLOCKA } \\
\hline \multicolumn{8}{|l|}{ Age group } \\
\hline 35 to 49 & 08 & 0.4482 & 2.80 & {$[0.2: 40.06]$} & - & - & - \\
\hline 50 to 59 & 12 & 0.8647 & 1.20 & [0.15:9.77] & - & - & - \\
\hline 60 to 77 & 07 & - & - & - & - & - & - \\
\hline \multicolumn{8}{|l|}{$B L O C K B$} \\
\hline \multicolumn{8}{|l|}{ Family income } \\
\hline $\mathrm{R} \$ 800.00$ to $\mathrm{R} \$ 1,800.00$ & 08 & 0.9116 & 1.12 & [0.14:8.99] & 0.8938 & 0.84 & [0.07: 10.03] \\
\hline Over $R \$ 3,000.00$ & 07 & 0.5247 & 2.25 & [0.18:27.37] & 0.4795 & 2.55 & [0.19:34.39] \\
\hline $\mathrm{R} \$ 2,000.00$ a $R \$ 3,000.00$ & 11 & - & - & - & - & - & - \\
\hline Could not inform & 01 & - & - & - & - & - & - \\
\hline \multicolumn{8}{|l|}{ Education } \\
\hline 0 to 8 & 15 & 0.5377 & 0.55 & [0.08:3.68] & 0.5835 & 0.58 & [0.08: 4.08] \\
\hline 12 to 16 & 12 & - & - & - & - & - & - \\
\hline \multicolumn{8}{|l|}{ BLOCKC } \\
\hline Do you smoke? & 04 & 0.9992 & - & - & 0.9992 & - & - \\
\hline Do you drink alcohol? & 06 & 0.7121 & 1.56 & {$[0.15: 16.72]$} & 0.7607 & 1.47 & [0.13: 17.18] \\
\hline Do you have or have you had hypertension? & 13 & 0.9180 & 0.91 & {$[0.15: 5.58]$} & 0.8055 & 0.79 & {$[0.11: 5.39]$} \\
\hline Do you have or have you had diabetes? & 03 & 0.0861 & 0.10 & [0.01: 1.39] & 0.9989 & - & - \\
\hline Do you have or have you had depression? & 03 & 0.9993 & - & - & 0.9994 & - & - \\
\hline Colesterol & 05 & 0.3033 & 0.33 & {$[0.04: 2.7]$} & 0.1916 & 0.13 & {$[0.01: 2.78]$} \\
\hline \multicolumn{8}{|l|}{ Medication } \\
\hline Antihypertensive & 13 & 0.9180 & 0.91 & {$[0.15: 5.58]$} & 0.8055 & 0.79 & [0.11:5.39] \\
\hline Antidepressant & 04 & 0.9992 & - & - & 0.9993 & - & - \\
\hline Antiulcerous & 04 & 0.1722 & 0.21 & [0.02: 1.97] & 0.1371 & 0.12 & [0.01: 1.95] \\
\hline Painkiller & 07 & 0.5626 & 2.00 & [0.19:20.9] & 0.7269 & 1.56 & [0.13: 18.88] \\
\hline Anti-lipidic & 06 & 0.0812 & 0.17 & [0.02: 1.25] & 0.0641 & 0.05 & [0: 1.19] \\
\hline Anti-inflammatory & 05 & 0.8947 & 1.18 & {$[0.11: 13.07]$} & 0.8322 & 1.40 & [0.06: 30.51] \\
\hline Oral antidiabetic & 03 & 0.0861 & 0.10 & {$[0.01: 1.39]$} & 0.9989 & - & - \\
\hline \multicolumn{8}{|l|}{ BMI Classification } \\
\hline Overweight / Excessive weight & 08 & 0.8928 & 0.86 & {$[0.09: 8.07]$} & 0.7537 & 0.69 & {$[0.07: 7.1]$} \\
\hline Obesity & 10 & 0.9056 & 1.14 & [0.13: 10.39] & 0.9781 & 0.97 & {$[0.1: 9.64]$} \\
\hline Normal weight & 09 & - & - & - & - & - & - \\
\hline Complaints in the oral cavity & & 0.9992 & - & - & 0.9992 & - & - \\
\hline Mouth sores (thrush, herpes etc.) & 04 & 0.9992 & - & - & 0.9992 & - & - \\
\hline Altered taste & 02 & 0.9994 & - & - & 0.9994 & - & - \\
\hline Swallowing problems & 05 & 0.9994 & - & - & 0.9994 & - & - \\
\hline Bleeding gums & 03 & 0.6278 & 0.53 & {$[0.04: 7.05]$} & 0.5302 & 0.41 & {$[0.03: 6.51]$} \\
\hline Dry mouth & 13 & 0.1082 & 6.67 & {$[0.66: 67.46]$} & $0.0430 *$ & 28.61 & [1.11: 735.71] \\
\hline Bad breath & 05 & 0.9991 & - & - & 0.9992 & - & - \\
\hline Chewing problems & 05 & 0.8947 & 1.18 & {$[0.11: 13.07]$} & 0.5790 & 2.07 & [0.16:27.2] \\
\hline Teeth sensitivity or pain & 05 & 0.3033 & 0.33 & {$[0.04: 2.7]$} & 0.3615 & 0.37 & [0.04:3.17] \\
\hline
\end{tabular}

Note: Logistic regression; $O R=$ odds ratio; ${ }^{*} P$ value less than 0.05
The use of antiemetics during chemotherapy contributed to the occurrence of xerostomia in the third and last session, since all women complained.

\section{DISCUSSION}

In this study, we identified the sensation of dry mouth before chemotherapy, which may occur due to climate change(18), such as low humidity in some regions in Brazil, especially in the city of São Paulo, as well as due to the adverse effects of some medications $^{(19)}$.

However, our results were not significant in this relationship between xerostomia and the use of previous medications. In contrast, in a study conducted in Brazil in 2018, with women undergoing treatment for breast cancer, the use of antihypertensive agents showed a xerostomia rate of $40.5 \%$. Still, in such a study, the xerostomia rate before the start of chemotherapy was $20.2 \%$, and the evaluation of this complaint was performed through sialometry ${ }^{(20)}$.

Sialometry is a method that consists of measuring salivary flow, which can be stimulated or not; the diagnosis of dry mouth is associated with hyposaliva$\operatorname{tion}^{(20)}$. However, the predictive value of this method is not well established, a fact demonstrated in the 2018 study in which $70 \%$ of patients complaining of previous dry mouth had normal salivary flow ${ }^{(21)}$.

Table 2 - Distribution of the studied population according to the chemotherapy regimen applied, São Paulo, Brazil, 2019

\begin{tabular}{|c|c|c|c|}
\hline Chemotherapy scheme & n (\%) & $\begin{array}{l}\text { Number of } \\
\text { sessions }\end{array}$ & Interval between sessions \\
\hline Paclitaxel (Taxol) & $03(11.1)$ & 8 and 16 & 7 days \\
\hline $\begin{array}{l}\text { Doxorubicin hydrochloride and cyclophosphamide followed by } \\
\text { trastuzumab / Herceptin }{ }^{\circledR}(A C+T H)\end{array}$ & $04(14.8)$ & 16 & 21 days in the first four doses and weekly in the posterior doses \\
\hline $\begin{array}{l}\text { Doxorubicin hydrochloride and cyclophosphamide followed by } \\
\text { Taxol }(A C+T)\end{array}$ & $15(55.6)$ & 16 & 21 days in the first four doses and weekly in the posterior doses \\
\hline Docetaxel and cyclophosphamide (TC) & $04(14.8)$ & 4 and 5 & 21 days \\
\hline Cyclophosphamide, methotrexate and fluorouracil (CMF) & $01(3.7)$ & 6 & 20 days \\
\hline Total of patients & 27 & & \\
\hline
\end{tabular}


Table 3 - Xerostomia for variables of interest (after the last chemotherapy session), São Paulo, Brazil, 2019

\begin{tabular}{|c|c|c|c|c|c|c|}
\hline & \multicolumn{3}{|c|}{ Gross } & \multicolumn{3}{|c|}{ Adjusted } \\
\hline & $p$ value & OR & $95 \% \mathrm{Cl}$ & $p$ value & OR & $95 \% \mathrm{Cl}$ \\
\hline \multicolumn{7}{|l|}{ BLOCKA } \\
\hline \multicolumn{7}{|l|}{ Age group } \\
\hline 35 to 49 & 0.6087 & 0.50 & {$[0.04: 7.1]$} & - & - & - \\
\hline 50 to 59 & 0.9987 & - & - & - & - & - \\
\hline 60 to 77 & - & - & - & - & - & - \\
\hline \multicolumn{7}{|l|}{ BLOCK B } \\
\hline \multicolumn{7}{|l|}{ Family income } \\
\hline $\mathrm{R} \$ 800,00$ to $\mathrm{R} \$ 1.800,00$ & 0.9989 & - & - & 0.9987 & - & - \\
\hline Over $\mathrm{R} \$ 3.000,00$ & 0.9989 & - & - & 0.9988 & - & - \\
\hline$R \$ 2.000,00$ to $R \$ 3.000,00$ & - & - & - & - & - & - \\
\hline \multicolumn{7}{|l|}{ Education } \\
\hline 0 to 8 & 0.4258 & 2.80 & [0.22: 35.29] & 0.3514 & 3.67 & [0.24: 56.54] \\
\hline 12 to 16 & - & - & - & - & - & - \\
\hline \multicolumn{7}{|l|}{ BLOCKC } \\
\hline Do you smoke? & 0.9992 & - & - & 0.9991 & - & - \\
\hline Do you drink alcohol? & 0.9991 & - & - & 0.9989 & - & - \\
\hline $\begin{array}{l}\text { Do you have or have you had } \\
\text { hypertension? }\end{array}$ & 0.5913 & 2.00 & [0.16: 25.11] & 0.7043 & 1.74 & {$[0.1: 30.66]$} \\
\hline Do you have or have you had diabetes? & 0.2333 & 0.18 & [0.01:3] & 0.9982 & - & - \\
\hline $\begin{array}{l}\text { Do you have or have you had } \\
\text { depression? }\end{array}$ & 0.9993 & - & - & 0.9994 & - & - \\
\hline Colesterol & 0.9991 & - & - & 0.9989 & - & - \\
\hline \multicolumn{7}{|c|}{ Medications (in use before chemotherapy) } \\
\hline Antihypertensive & 0.5913 & 2.00 & [0.16: 25.11] & 0.7043 & 1.74 & {$[0.1: 30.66]$} \\
\hline Antidepressant & 0.9992 & - & - & 0.9992 & - & - \\
\hline Antiulcerous & 0.0307 & $0.05^{*}$ & [0: 0.75] & 0.9978 & - & - \\
\hline Painkiller & 0.1255 & 0.13 & [0.01: 1.76] & 0.9982 & - & - \\
\hline Anti-lipidic & 0.6278 & 0.53 & {$[0.04: 7.05]$} & 0.8381 & 0.74 & [0.04: 13.9] \\
\hline Anti-inflammatory & 0.9991 & - & - & 1.0000 & - & - \\
\hline Oral antidiabetic & 0.2333 & 0.18 & [0.01:3] & 0.9982 & - & - \\
\hline \multicolumn{7}{|l|}{$\begin{array}{l}\text { Medications (in use during all } \\
\text { chemotherapy administrations) }\end{array}$} \\
\hline Antihypertensive & 0.5054 & 2.36 & [0.19: 29.71] & 0.4827 & 3.08 & [0.13: 70.86] \\
\hline Antidepressant & 0.9991 & - & - & 0.9991 & - & - \\
\hline Antiulcerous & 0.4258 & 0.36 & {$[0.03: 4.5]$} & 0.4234 & 0.26 & {$[0.01: 7.01]$} \\
\hline Painkiller & 0.9986 & - & - & 0.9983 & - & - \\
\hline Anti-lipidic & 0.2859 & 4.00 & [0.31: 51.03] & 0.4184 & 3.20 & [0.19: 53.68] \\
\hline Anti-inflammatory & 0.6278 & 0.53 & {$[0.04: 7.05]$} & 0.8381 & 0.74 & [0.04: 13.9] \\
\hline Oral antidiabetic & 0.9991 & - & - & 0.9989 & - & - \\
\hline Antihypertensive & 0.3610 & 0.29 & [0.02: 4.2] & 0.9981 & - & - \\
\hline \multicolumn{7}{|l|}{ BMI Classification } \\
\hline Overweight / Excessive weight & 0.9989 & - & - & 0.9988 & - & - \\
\hline Obesity & 0.6003 & 0.50 & [0.04: 6.68] & 0.9980 & - & - \\
\hline Normal weight & - & - & - & - & - & - \\
\hline \multicolumn{7}{|l|}{ Complaints in the oral cavity } \\
\hline Mouth sores (thrush, herpes etc.) & 0.3610 & 0.29 & [0.02: 4.2] & 0.6674 & 0.51 & [0.02: 11.31] \\
\hline Altered taste & 0.9995 & - & - & 0.9994 & - & - \\
\hline Swallowing problems & 0.1257 & 0.09 & [0.004: 1.98] & 0.9986 & - & - \\
\hline Bleeding gums & 0.9993 & - & - & 0.9992 & - & - \\
\hline Dry mouth & 0.5913 & 2.00 & [0.16: 25.11] & 0.7043 & 1.74 & {$[0.1: 30.66]$} \\
\hline Bad breath & 0.9991 & - & - & 0.9991 & - & - \\
\hline Chewing problems & 0.9991 & - & - & 0.9990 & - & - \\
\hline Teeth sensitivity or pain & 0.4946 & 0.40 & [0.03: 5.55] & 0.4230 & 0.26 & [0.01: 6.95] \\
\hline
\end{tabular}

Nota: Regressão logística; *OR = odds ratio $(1 / 0,05 \sim 22)$.
On the other hand, in a study of Indian women diagnosed early with breast cancer, there was an absence of xerostomia before chemotherapy, but this condition appeared during treatment and persisted even after 12 weeks $^{(14)}$.

In our study, a high prevalence of xerostomia during chemotherapy was identified regardless of the chemotherapy regimen used and in any session. This corroborates other works already done to reinforce the idea that chemotherapeutic agents have an important action on the cells of the oral mucosa epithelium, contributing to the appearance of xerostomia and other oral manifestations ${ }^{(13,22)}$.

A study carried out in 2017 showed a higher prevalence of xerostomia during chemotherapy in patients who used continuous medication (17.92\%) than in those who did not use it $(5.52 \%)^{(21)}$. This association was demonstrated by our results only with the use of antiemetics; the other drugs had no significance in relation to xerostomia.

Antiemetics are widely prescribed during chemotherapy in hospitals, outpatient clinics and at home, especially serotonin receptor antagonists such as ondansetron, however there are few studies that describe their action and side effects in this scenario(23).

In 2014, a study was carried out to assess the impact of antiemetics on the control of emesis in patients with breast cancer undergoing chemotherapy, and concluded that they are not effective in preventing or treating chemotherapy-induced nausea and vomiting ${ }^{(23)}$.

In this study, the side effects of these drugs were not described; in contrast, a study carried out in 2018 showed that antiemetics are effective in the treatment of vomiting in children and that they have a reduced number of side effects ${ }^{(24)}$. 
Another work, carried out in 2006, highlighted the side effect that some drugs have depending on their action in the body, such as the anti-cholinergic of antiemetics, confirming our results; the sympathomimetics of antidepressants, with no significance in our analysis; and that of anti-ulcers, which can lead to xerostomia ${ }^{(19)}$, whose use we show to present itself as a protective factor.

According to the 2017 World Health Organization (WHO) report, there was an $18 \%$ worldwide increase in the number of people with depression (2005 to 2015), reaching 11.5 million people in Brazil, which corresponds to $5.8 \%$ of the population ${ }^{(25)}$.

A bibliographic study carried out in 2017 described the main drugs with potential for side effects in the oral cavity, including tricyclic antidepressants and selective serotonin reuptake inhibitors, which act on the oral mucosa reducing salivary flow, which can cause discomfort and others consequences such as gingivitis, glossitis and dry mouth ${ }^{(26)}$. Thus, once again, the evaluation of xerostomia was correlated with the decrease in salivary flow, contrary to what was presented in a 2018 study ${ }^{(21)}$.

To date, we have not identified studies similar to ours regarding the evaluation of xerostomia in women with breast cancer undergoing chemotherapy.

\section{Study limitations}

This study has some limitations regarding both the sample size resulting from the time of treatment and the discussion of results due to the scarcity of publications with the same method of xerostomia evaluation.

\section{Contributions to the area of Nursing, Health or Public Policy}

Our study contributes to the nursing team that serves this population by informing the high prevalence of xerostomia not only during chemotherapy and by stimulating the development of protocols aimed at reducing this complaint even before the start of therapy.

\section{CONCLUSION}

We identified a high prevalence of xerostomia in women with breast cancer regardless of the chemotherapy regimen employed.

Variables such as age, tobacco use, alcoholic beverages, antihypertensives, analgesics, oral antidiabetics and corticosteroids did not influence this prevalence; on the other hand, antiemetics contributed to its appearance in the third and last session.

Anti-ulcers were presented as a protective factor, but this result requires further studies, as the group of patients who used this medication was small.

The report of dry mouth before the start of therapy alerts us to the importance of creating protocols that reduce this complaint and all other problems related to it, contributing to the quality of life of these patients.

\section{REFERENCES}

1. Global Cancer Observatory® International Agency for Research on Cancer[Internet]. 2020 [cited 2020 May 11]. Available fom: http://gco.iarc.fr/

2. Ministério da Saúde (BR). Instituto Nacional de Câncer José Alencar Gomes da Silva. Coordenação de Prevenção e Vigilância. Estimativa 2020: Incidência de Câncer no Brasil. Rio de Janeiro: INCA. [Internet]. 2019[cited 2020 May 11];122p. Available from: https://www.inca.gov. br/publicacoes/livros/estimativa-2020-incidencia-de-cancer-no-brasil

3. Ministério da Saúde (BR). Instituto Nacional de Câncer José Alencar Gomes da Silva. Coordenação de Prevenção e Vigilância. Estimativa 2018: Incidência de Câncer no Brasil. Rio de Janeiro: INCA. [Internet]. 2017[cited 2019 Oct 24];128p. Available from: https://www.inca.gov.br/ imprensa/inca-estima-que-havera-cerca-de-600-mil-casos-novos-de-cancer-em-2018

4. Cordeiro LAM, Nogueira DA, Gradim CVC. Women with breast cancer in adjuvant chemotherapy: assessment of quality of life. Rev Enferm UERJ [Internet]. 2018[cited 2019 Oct 19];26:e17948. Available from: https://www.e-publicacoes.uerj.br/index.php/enfermagemuerj/article/view/17948

5. Agostini BA, Cericato GO, Silveira ER, Nascimento GG, Costa FS, et al. How common is dry mouth? systematic review and meta-regression analysis of prevalence estimates. Braz Dent J [Internet]. 2018[cited 2019 Oct 19];29(6):606-18. Available from: https://www.ncbi.nlm.nih.gov/ pubmed/30517485

6. Menezes AC, Rosmaninho E, Raposo B, Alencar MJS. Abordagem clínica e terapêutica da mucosite oral induzida por radioterapia e quimioterapia em pacientes com câncer. Rev Bras Odontol [Internet]. 2014[cited 2019 Oct 24];71(1):35-8. Available from: http://revodonto. bvsalud.org/pdf/rbo/v71n1/a07v71n1.pdf

7. Menezes JR, Luvisaro BMO, Rodrigues CF, Muzi CD, Guimarães RM. Test-retest reliability of Brazilian version of Memorial Symptom Assessment Scale for assessing symptoms in cancer patients. Einstein (São Paulo) [Internet]. 2017[cited 2019 Oct 19];15(2):148-54. Available from: https://journal.einstein.br/pt-br/article/confiabilidade-teste-reteste-da-versao-brasileira-do-instrumento-memorial-symptomassessment-scale-para-avaliacao-de-sintomas-em-pacientes-oncologicos/

8. Volpato LER, Silva TC, Oliveira TM, Sakai VT, Machado MAAM. Radiation therapy and chemotherapy-induced oral mucositis. Rev Bras Otorrinolaringol. 2007;73(4):562-68. doi: 10.1590/S0034-72992007000400017

9. Cheng YM, Lan SH, Hsieh YP, Lan SJ, Hsu SW. Evaluate five different diagnostic tests for dry mouth assessment in geriatric residents in long-term institutions in Taiwan. BMC oral health [Internet]. 2019[cited 2019 Oct 19];19:106. Available from: https://bmcoralhealth. biomedcentral.com/articles/10.1186/s12903-019-0797-2

10. Johansson AK, Johansson A, Unell L, Ekbäck G, Ordell S, Carlsson GE. A 15-yr longitudinal study of xerostomia in a Swedish population of 50-yr-old subjects. Europ J Oral Sci. 2009;117(1):13-9. doi: 10.1111/j.1600-0722.2008.00597.x 
11. Johansson AK, Johansson A, Unell L, Ekbäck G, Ordell S, Carlsson GE. Self-reported dry mouth in 50- to 80-year-old Swedes: longitudinal and cross-sectional population studies. J Oral Rehabil[Internet]. 2020[cited 2020 Jan 20];47:246-54. Available from: https://onlinelibrary.wiley. com/doi/epdf/10.1111/joor.12878

12. Costa AM, Fonseca EP, Fonseca DAV, Sousa MLR. Distribuição espacial da xerostomia e índice de exclusão social de idosos de Piracicaba, SP. Arq Odontol[Internet]. 2015[cited 2019 Oct 19];51(1):39-46. Available from: http://revodonto.bvsalud.org/pdf/aodo/v51n1/a05v51n1.pdf

13. Araujo TLC, Mesquita LKM, Vitorino RM, Macedo AKMN, Amaral RC, Silva TF. Manifestações bucais em pacientes submetidos a tratamento quimioterápico. Rev Cuba Estomatol[Internet]. 2015[cited 2019 Oct 24];52(4):16-21. Available from: http://www.revestomatologia.sld.cu/ index.php/est/article/view/832/218

14. Acharya S, Pai KM, Bhat S, Mamatha B, Bejadi VM, Acharya S. Oral changes in patients undergoing chemotherapy for breast cancer. Indian J Dent Res. [Internet]. 2017[cited 2019 Oct 24];28(3):261-8. Available from: https://www.ncbi.nlm.nih.gov/pubmed/28721989

15. Thomson WM, Chalmers JM, Spencer AJ, Williams SM. The Xerostomia Inventory: a multi-item approach to measuring dry mouth. Community Dent Health[Internet]. 1999[cited 2019 Oct 24];16(1):12-7. Available from: https://pubmed.ncbi.nlm.nih.gov/10697349/

16. Mata ADSP, Marques DNS, Freitas FMF, Amaral JPAR, Trindade RTVMR, Barcelos FAD, et al. Translation, validation, and construct reliability of a Portuguese version of the Xerostomia Inventory. Oral Dis [Internet]. 2012[cited 2019 Oct 24];18:293-98. Available from: https://www.ncbi. nlm.nih.gov/pubmed/22151408

17. Souza R, Fraga JS, Gottschall CBA, Busnella FM, Rabito El. Avaliação antropométrica em idosos: estimativas de peso e altura e concordância entre classificações de IMC. Rev Bras Geriatr Gerontol. 2013;16(1):81-90. doi: 10.1590/S1809-98232013000100009

18. Souza CG, Sant'Anna Neto JL. Ritmo climático e doenças respiratórias: interação e paradoxos. Rev Bras Climatol [Internet]. 2008[cited 2019 Oct 24];65-82. Available from: https://revistas.ufpr.br/revistaabclima/article/view/25424

19. Fávaro RAA, Ferreira TNR, Martins WD. Xerostomia: etiologia, diagnóstico e tratamento. Clin Pesqui Odontol [Internet]. 2006[cited 2019 Oct 24];2(4):303-17. Available from: https://periodicos.pucpr.br/index.php/oralresearch/article/view/23003

20. Musso MAA, Calmon MV, Pereira LD, Brandão-Souza C, Amorim MHC, Zandonade E, et al. Associação das Manifestações Bucais com Variáveis Sociodemográficas e Clínicas em Mulheres com Câncer de Mama. Rev Bras Ciên Saúde[Internet]. 2018[cited 2019 Oct 24];22(3):203-2012. Available from: https://pesquisa.bvsalud.org/portal/resource/pt/biblio-914456

21. Niklander S, Veas L, Barrera C, Fuentes F, Chiappini G, Marshall M. Risk factors, hyposalivation and impact of xerostomia on oral healthrelated quality of life. Braz Oral Res. 2017;31(1):1-9. doi: 10.1590/1807-3107BOR-2017.vol31.0014

22. Freire AA, Honorato PM, Macedo SB, Araújo CS. Manifestações bucais em pacientes submetidos a tratamento quimioterápico no hospital de câncer do Acre. J Amazon Health Sci [Internet]. 2016[cited 2019 Oct 24];2(1):1-21. Available from: https://periodicos.ufac.br/index.php/ahs/ article/view/315

23. Castro MS, Araújo AS, Mendes TR, Vilarinho GS, Mendonça MAO. Eficácia dos antieméticos no controle da emese induzida por quimioterapia antineoplásica em casa. Acta Paul Enferm. 2014:27(5):412-8. doi: 10.1590/1982-0194201400069

24. Epifanio M, Portela JL, Piva JP, Ferreira CHT, Sarria EE, Mattiello R. Bromoprida, metoclopramida ou ondansetrona no tratamento de vômito no departamento de emergência pediátrica: ensaio controlado randomizado. J Pediatr. 2018:94(1):62-8. doi: 10.1016/j.jped.2017.06.004

25. World Health Organization (WHO). Depression and other common mental disorders: global health estimates [Internet]. Geneve: WHO; 2017. [cited 2020 May 14]. Available from: https://www.who.int/mental_health/management/depression/prevalence_global_health_estimates/en/

26. Pires AB, Madeira ACA, D’Araújo KM, Grossi LDS, Valadão AF, Motta PG. Reações adversas na cavidade oral em decorrência do uso de medicamentos. Rev Salusvita [Internet]. 2017 [cited 2020 May 14]:36(1):157-85. Available from: https://secure.unisagrado.edu.br/static/ biblioteca/salusvita/salusvita_v36_n1_2017_art_12.pdf 